\title{
Inversion and exhumation of the St. George's Channel basin, offshore Wales
}

\author{
${ }^{1}$ Gareth Williams, ${ }^{2}$ Jonathan Turner, ${ }^{2}$ Simon Holford \\ ${ }^{1}$ British Geological Survey, Nicker Hill, Keyworth, Nottingham NG12 5GG, gwil@bgs.ac.uk \\ ${ }^{2}$ University of Birmingham, School of Geography, Earth \& Environmental Sciences, \\ Birmingham B15 2TT
}

8204 words, 17 figures, 46 references

\begin{abstract}
The western UK basins of the Irish Sea have provided one of the best natural laboratories for investigating the causes and consequences of intracratonic uplift and erosion (exhumation). To date, the emphasis has been on igneous underplating as the chief process driving their exhumation. In this paper, we demonstrate that tectonic inversion - the shortening of formerly extensional basins and reactivation of their constituent faults - dominated the exhumation of the St. George’s Channel basin, offshore Wales. Based on mapping of an extensive 2D seismic grid, evidence is presented for at least two major inversion episodes in the Late Cretaceous and the Neogene, plus minor shortening during the Eocene. Inversion was distinctly noncoaxial, especially during the Neogene when coeval transpression and transtension was focused at discrete bends and stepovers on the basin-bounding St. George's, Bala and Northwest Flank faults. That the principal mechanism driving these uplift episodes was inversion (as opposed to igneous underplating) is corroborated by analysis of thermal history data (apatite fission track and vitrinite reflectance). They reveal late Cretaceous and Neogene geothermal gradients that were comparable with the present day i.e. no significant increase in basal heatflow. Sonic velocity profiles logged in hydrocarbon boreholes constrain the minimum thickness of the eroded section which varies between c. $1000 \mathrm{~m}$ in the centre and c. $2240 \mathrm{~m}$ at the margins of the basin. Given the strength of evidence for tectonic inversion in the St. George's Channel basin, our favoured model invokes superimposition of the effects of inversion and igneous underplating to account for the complex exhumation history of the St. George's Channel basin in particular, and the western UK basins in general.
\end{abstract}

\section{KEYWORDS:}

ABBREVIATED TITLE: Inv. \& Exh. of the SGCB 
Intracratonic basinsadjacent to 'passive' ocean margins undergo uplift in response to a diverse range of processes related chiefly to i) epeirogeny (i.e uplift of broad regions of continental interiors), and ii) intraplate shortening and tectonic inversion. Sedimentary basin inversion, the compressional or transpressional reactivation and shortening of formerly extensional basins, can have a marked influence on the structure and evolution of the basin fill. It follows that inversion has major implications for the exhumation of petroliferous basins, where the attendant cooling and lithostatic pressure release affects hydrocarbon generation and retention directly (e.g. Dore et al. 2002).

Reconstructing the tectonic history of the western UK basins is hampered by the difficulty in recognizing and discriminating the superimposed effects of epeirogeny and inversion. This paper reports on the results of recent mapping of an extensive seismic dataset imaging the SE margin of the St. George's Channel basin (SGCB; Fig. 1). The focus of this mapping has been to determine the geometry, kinematics and timing of deformation associated with the Cretaceous-Cenozoic inversion of the NW European 'Alpine' foreland. This was a key period in the development of the sedimentary basins and associated petroleum systems of the western UK basins during which they were affected directly by plate margin processes associated with i) fragmentation of the Eurasian-North American plate (chiefly North Atlantic opening) and ii) Alpine orogenesis.

Seismic data on their own provide only loose constraints on the timing of inversion episodes and the magnitude of the resultant uplift and erosion (exhumation). Consequently, the picture from the seismic data is augmented by information from thermal history reconstruction (THR; in this case, apatite fission track analysis and vitrinite reflectance) to constrain the timing and driving mechanism of exhumation episodes, and THR and sonic velocities to yield information on the magnitude of exhumation. Thermal history reconstruction seeks to identify periods of long-term cooling of sedimentary basins, the principal manifestation in the rock record of major episodes of exhumation. Vertical sonic velocity profiles provide an effective measure of the maximum burial depth of exhumed sedimentary successions because their long wavelength form (depth range $>1 \mathrm{~km}$ ) responds chiefly to compaction-driven porosity reduction.

\section{Regional structure}

The SGCB is well placed in the western UK basin system to evaluate the contribution of tectonic inversion to regional uplift. First, it contains one of the thickest and most complete Jurassic successions on the UK continental shelf, and over a kilometre of Cenozoic rocks (Tappin et al. 1994). Unlike the East Irish Sea basin, where Triassic rocks outcrop at the seafloor, the geometry, kinematics and timing of post-Triassic inversion episodes can be mapped using seismic data. 
Secondly, the SGCB spans the key transition between the manifestly inverted basins of southern Britain (e.g. Wessex, Bristol Channel, Celtic Sea basins) and those more deeply eroded basins to the north whose exhumation appears to have been dominated by epeirogenic processes (e.g. East Irish Sea basin).

The thick sedimentary fill of the SGCB is expressed clearly on the free-air gravity anomaly map shown in Figure 1 where a gravity low of -30-35 mGal signifies the main Mesozoic depocentre. It comprises two roughly circular negative anomalies separated by a markedly low-gradient zone of slightly less negativity. This corresponds to a NW-oriented inversion anticline manifested also by the regional structure at basal- and intra-Cenozoic levels (see Figs. 2iii \& 2iv). The SGCB is approximately $100 \mathrm{~km}$ x $50 \mathrm{~km}$ and contains a post-Carboniferous succession up to $12 \mathrm{~km}$ thick (Ref. - Welch \& Turner or Tappin ?). To the NW and SE, this depocentre is bounded by positive gravity anomalies corresponding to zones of crustal thinning (Blundell et al. 1972). The SGCB is separated from the Central Irish Sea basin by the Northwest Flank Fault (an extension of the Menai StraitsSouth Irish Sea Lineament), while the SE flank of the basin comprises two NE-trending fault zones (the St. George's Fault and the Bala Fault) separated by a fault-dissected terrace. To the north, the Codling Fault marks the boundary between the SGCB and the Cardigan Bay basin, while the Sticklepath Fault Zone marks the southern limit of the SGCB. These faults form part of a regional fault system (Figure 3) which linked the opening North Atlantic with the Bresse-Rhone-Ligurian rift during the Cenozoic (Coward 1994) and accommodated stress generated by the Eocene closure of the Bay of Biscay (Lefort \& Agarwal 2000).

\section{Seismic interpretation - database and methods}

The seismic database utilized in this study (Fig. 1) comprises 178 closely spaced 2D migrated seismic profiles acquired as parts of three separate surveys between 1983 and 1996. These data cover a total $3000 \mathrm{~km}^{2}$ with a mean grid cell size of some $1.5 \mathrm{~km}^{2}$. Based on information tied into the seismic data from 12 wells drilled between 1974 and 1990, interpretations and maps are presented here for the base and top of the Triassic succession, basal Cenozoic and Eocene levels (Fig. 2). As well as providing stratigraphic constraints on seismic interpretations, sonic velocity and vitrinite reflectance data acquired from these wells have been used to compute the thickness of sedimentary section eroded during the exhumation episodes inferred from the seismic data.

The following four tectono-stratigraphic sequences are identified from well logs and seismic lines in the SGCB (Fig. 4). 
1) Dinantian limestone and thick deltaic sandstone and shale cyclothems throughout the Silesian (Upper Carboniferous). The limestones are manifested on seismic profiles by a thick package of high-amplitude reflectors capped by the seismically quiet Silesian siliciclastics in which there are few internal reflectors.

2) A syn-rift succession resting unconformably on Carboniferous rocks. The syn-rift was deposited during discrete rift events in the Permo-Triassic and Upper Jurassic (Welch \& Turner 2000) and is sub-divided into four major units: Unit 1 includes the alluvial Sherwood Sandstone Group and the paralic Mercia Mudstone Group; Unit 2 is a Lower Jurassic succession incorporating the Lias Group that accumulated on an open marine shelf (Dobson \& Whittington 1987); Unit 3 is the Middle Jurassic and includes the Inferior and Great Oolite Groups deposited in high-energy shallow water conditions; Unit 4 comprises the Upper Jurassic Oxford and Kimmeridge Clay Formations recording shallow marine and deltaic sedimentation. In terms of its seismic signature, Sequence 2 is dominated by numerous highfrequency reflectors within the Mercia Mudstone (especially on the eastern basin margin), and high-amplitude reflectors throughout the Jurassic succession representing thin limestone packages within an overall fine-grained siliciclastic succession.

3) Sandstone-dominated continental fluvial rocks of Eocene-Oligocene age, with periodic marine incursions. The Cenozoic is generally horizontally bedded and across most of the study area it rests with pronounced unconformity on folded Jurassic strata. Seismically prominent Eocene and Oligocene coals can be mapped across the extent of the study area.

4) A thin veneer of flat-lying Plio-Pleistocene and Quaternary glacial sediments.

\section{Inversion structures - geometry and kinematics}

The SGCB exhibits the geometry of a large-scale 'pop-up', or reverse flower structure, with expulsion of the basinfill accommodated by reverse displacement on the divergent Northwest Flank and Bala Faults. A cross-section through the St. Tudwal's Arch (Fig. 5) exemplifies many of the key features of the inversion of the SGCB and contiguous areas. The St. Tudwal's Arch is a large structural culmination which, since the Carboniferous, has been reactivated and uplifted during multiple inversion episodes in the Cretaceous and Cenozoic. A SE-ward thickening wedge of Jurassic rocks is truncated at the present seafloor due to uplift focused on fault systems rooted in the PrecambrianOrdovician core of the St. Tudwal's Arch. The uplifted flanks of this culmination (Fig. 6) are overlain with angular unconformity by Eocene-Oligocene deposits which, at the crest of the St. Tudwal's Arch, are themselves eroded at the present seafloor due to Neogene inversion. Except for a small pocket preserved in the Central Irish Sea basin, Cretaceous rocks are almost entirely absent across the area (Cope 1998). 
Detailed seismic images through the Bala Fault (Figs. 7 \& 8) emphasize the along-strike variability in the inversion geometry of this margin of the basin. The main structure in the hanging wall of the Bala Fault is that of a rollover anticline - the Morfa structure - that formed during Triassic-early Jurassic extension. It comprises a low-angle, ramp-flat detachment (Fig. 7) that carried a CarboniferousMesozoic succession NW-ward in response to extensional collapse of the SGCB margin during the early Jurassic (Turner 1996). Subsequent reactivation of this extensional detachment reversed the sense of hanging wall displacement resulting in tightening and amplification of the Morfa structure.

Like the Northwest Flank Fault, the Bala Fault was reactivated during Cretaceous and Neogene inversion with compressional strain restricted mainly to right-stepping jogs along the fault (Fig. 2iii). The severity of inversion increases markedly toward the NE where the buttressing effect of the intersection of the Bala and Codling Faults is interpreted to have focused transpressional strain. Thus, in the NE of the study area shortening is accommodated by an antithetic reverse fault splaying from the Bala Fault that duplicates a c.1s TWT Triassic interval (Fig. 8). Further south, however, tightening of the Morfa Structure is accommodated by steepening of its forelimb (Fig. 7) and, to the south of this study area, the fault maintains an extensional geometry (Welch \& Turner 2000). A BGS shallow borehole penetrated Eocene-Oligocene strata on the SE flank of the Morfa Structure (Fig. 2iii). We interpret these strata to be an erosional remnant of the thick Cenozoic sequence that blankets the rest of the SGCB (c.0.8s TWT Palaeogene rocks preserved in the hanging wall of the Bala Fault: Fig. 8). This interpretation implies that at least $800 \mathrm{~m}$ of Palaeogene rocks were eroded during OligoceneMiocene inversion (assuming a Cenozoic interval velocity of $2000 \mathrm{~m} / \mathrm{s}$ ).

Figures 2iii) \& 2iv) show a broad, gentle anticline whose axial trace is oriented roughly NW. Its confinement to basal- and intra-Cenozoic levels is typical of the evidence used to recognize inversion tectonics (Turner \& Williams 2004). The St. George's Fault is a complex structure which changes from net normal to reverse offset along strike (Figure 2ii). Because fault systems evolve during many increments of coseismic slip, fault displacement will increase progressively from the tip of a normal fault, where it is zero, to its centre where it is maximal. Subsequent reverse reactivation of a normal fault means that the fault tip regions will display net reverse offset before the centre. Consequently, segments of net reverse and net normal displacement will be separated by the so called null point at which fault displacement is zero.

Planview structural geometry of the SGCB attests to the significance of strike-slip kinematics in its formation and inversion. Figure 2iii) illustrates several examples where transpressional deformation is concentrated in the immediate vicinity of right-stepping bends on the St. George’s Fault. A crosssection through one such transpressional jog (Fig. 9) reveals a small thrust fault detaching within Upper Triassic evaporites. Pronounced thickening, or growth, of the Eocene-Oligocene interval on the 
downthrown side of this thrust indicates that it was active during the late Palaeogene. Several instances of localized Cenozoic pull-apart basins record transtensile strain during the Palaeogene and early Neogene. One such basin (Fig. 10) is bounded by one of an array of en-echelon normal faults whose geometry is consistent with NE-oriented left-lateral shear (Fig. 2iii).

\section{Exhumation estimates from analysis of sonic velocities}

\section{Method}

In common with other approaches to sonic velocity analysis, this study employs the exponential decrease of porosity with burial depth to compute exhumation magnitude (e.g. Magara 1976, Issler 1992, Heasler \& Kharitonova 1996; Hillis 1995, Ware \& Turner 2002):

$$
\phi=\phi_{0} \exp ^{(-\mathrm{bx})}
$$

where $\phi=$ porosity at depth $\mathrm{x}, \phi_{0}=$ surface porosity of uncompacted sediment and $\mathrm{b}=$ compaction coefficient per unit lithology (Athy 1930). Because mechanical compaction is a largely irreversible phenomenon, it follows that overcompacted sedimentary units (i.e. buried shallower than they have been in the past) will exhibit anomalously low porosity ('burial anomaly' of Japsen 1998). Our approach follows that described in detail by Menpes \& Hillis (1995) in which interval transit times (ITT - the reciprocal of interval velocity) from wells drilled in an exhumed basin are compared with a normal compaction curve for a ubiquitous, uniform lithology (Mercia Mudstone Formation):

$$
\mathrm{E}_{\mathrm{A}}=\frac{1}{m}\left(\Delta t_{u}-\Delta t_{o}\right)-d_{u}
$$

where $\frac{1}{m}$ is the gradient of the normal compaction trend, $t_{u}$ is the mean formation ITT for each well, $\Delta t_{o}$ is the constant of the normal compaction trend (i.e. ITT of uncompacted sediment) and $\mathrm{d}_{\mathrm{u}}$ is the depth of the formation midpoint below the seabed (see also Fig. 11). This method yields a value for apparent exhumation $\left(E_{A}\right)$, the thickness of eroded overburden referenced to a discrete unconformity surface. Thus, to gain an estimate of total exhumation $\left(\mathrm{E}_{\mathrm{T}}\right)$ it is necessary to add the thickness of postexhumation burial to $\mathrm{E}_{\mathrm{A}}$.

\section{Results}

Analysis of interval transit times from 13 wells from exhumed settings in the SGCB yields two broad trends (Fig. 11):

1. Exhumation between $1.0 \mathrm{~km}-1.39 \mathrm{~km}$ (relative to the reference trend) for wells from the central part of the basin.

2. Exhumation between $2.08 \mathrm{~km}-2.24 \mathrm{~km}$ (relative to the reference trend) for wells located near to the NW basin margin. 
The consistency of anomalous velocity-depth relations with local geology lends support to their interpretation in terms of overcompaction rather than lithological and intraformational effects (e.g. overpressure, anomalously cemented zones, salt horizons). Thus, the three most exhumed well locations (106/18-1, 42/16-1, 42/17-1) are all characterized by exposure of Triassic rocks at the seabed. On the SE margin of the basin, where exhumation was around $1.3 \mathrm{~km}$, Cenozoic rocks rest unconformably on a Triassic and Lower Jurassic succession. The difference in exhumation between depocentre and marginal settings is interpreted as a reflection of the contribution of inversion to regional uplift. Inversion-related uplift was most pronounced at the basin margins where reactivation of the Bala and Northwest Flank faults accommodated overall extrusion of the basinfill (e.g. Morfa structure: Figs. 7 \& 8). Conversely, inversion-related exhumation was less in the depocentre because i) uplift was less pronounced there, and ii) deeper bathymetry means that uplift was not necessarily accompanied by erosion.

A plot of exhumation derived from the Mercia Mudstone Formation of the SGCB with Mercia Mudstone data from the South Celtic Sea basin (Fig. 12) shows comparable values (exhumation in the South Celtic Sea basin varies between $1.10 \mathrm{~km}-1.67 \mathrm{~km}$ ). This further supports the interpretation of anomalous velocity-depth relationships within the Mercia Mudstone Formation in terms of overcompaction.

\section{Exhumation estimates from thermal history analysis}

\section{Method}

The fact that temperature increases progressively with depth within the lithosphere means that palaeothermal indicators such as apatite fission track and vitrinite reflectance data can be used to assess the former burial depths of rock units (Green et al. 2002). Sedimentary units are progressively heated during burial and begin to cool at the initiation of exhumation. Apatite fission-track and vitrinite reflectance data provide quantitative estimates of the temperatures attained by individual rock samples at a palaeo-thermal maximum, prior to the onset of cooling (Green et al. 1995, 2002). Vitrinite reflectance data can provide discrete estimates of maximum post-depositional palaeotemperatures, whilst apatite fission track data can provide either upper or lower limits, or a range of values for the maximum palaeotemperature in up to three separate palaeo-thermal episodes (Bray et al. 1992; Green et al. 2002). In exhumed basins like those of the western UK, palaeotemperatures derived from apatite fission track and vitrinite reflectance data through a vertical rock section can be used to estimate palaeogeothermal gradients. Moreover, by extrapolation to an assumed palaeo-surface temperature, the thickness of section removed during exhumation can be quantified (Green et al. 2002). Full methodological descriptions of the analytical and interpretative procedures by which thermal history 
data are extracted from apatite and vitrinite samples are provided by Gallagher et al. (1998) and Green et al. (2002).

The analysis of a series of apatite and vitrinite samples over a range of depths (e.g. in an exploration well) reveals the variation of maximum palaeotemperature with depth, and the form of the 'palaeotemperature profile' characterising a particular palaeo-thermal episode can provide vital information on the likely mechanisms of heating and cooling during that episode. If the temperature profile within a sedimentary succession was a consequence of a distinct thermal event, then thermal indicators will record an increased palaeogeothermal gradient. Conversely, if maximum palaeotemperatures reflect sediment burial and subsequent exhumation, the recorded geothermal gradient will be similar to the present day value with higher maximum temperatures for a given depth. In this case the amount of missing section (D) can be estimated from the temperature-depth profile. Alinear geothermal gradient is assumed:

$$
D=\frac{T_{i}-T_{s}}{\left(\frac{d_{t}}{d_{z}}\right)}
$$

where $T_{i}$ is the extrapolated palaeotemperature corresponding to the present day surface, $T_{s}$ is the surface temperature and $\left(\frac{d_{t}}{d_{z}}\right)$ is the palaeogeothermal gradient at the time of the recorded maximum palaeotemperature (Bray et al. 1992).

\section{Results}

Apatite fission track and vitrinite reflectance data from the SGCB provide further evidence for its exhumation during the Late Cenozoic. Data from well 106/24a-2b are typical. The maximum palaeotemperatures of twenty two vitrinite samples from the Palaeogene and Jurassic intervals in 106/24a-2b were determined using the kinetic model of Burnham \& Sweeney (1989), assuming a heating rate of $1^{\circ} \mathrm{C} / \mathrm{Ma}$. (Fig. 13a). From the maps presented in Figure 2, it is apparent that the well tested the crest of an anticline that formed during the Cenozoic. The intercept on the temperature axis of Figure 13a shows that the vitrinite reflectance-derived palaeotemperatures are mostly $>30^{\circ} \mathrm{C}$ higher than the present day temperatures. Palaeotemperature estimates from the two apatite fission track samples from 106/24a-2b are in good agreement with those from the VR data which, collectively, define a linear gradient. This palaeotemperature profile is more or less parallel to the present-day geothermal gradient suggesting that the palaeotemperature data record heating due to deeper burial rather than increased basal heatflow. 
The continuity of palaeotemperatures across the Jurassic/Cenozoic unconformity for two wells, shown in Figure 14, implies that maximum palaeotemperatures over all depths within this well were attained following deposition of the Palaeogene section, prior to exhumation-related cooling. Although the thermal history data provide no direct evidence for late Cretaceous-early Cenozoic cooling, they are consistent with appreciable exhumation having occurred, assuming that the thickness of eroded section did not exceed that accumulated during subsequent burial.

Estimates of palaeogeothermal gradient at well 106/24a-2b and the thickness of the eroded section have been obtained using the statistical techniques of Bray et al. (1992). The results from 106/24a-2b (Fig. 13b) define a maximum likelihood estimate of $29^{\circ} \mathrm{C} / \mathrm{km}$ for the post-Palaeogene palaeogeothermal gradient, with an allowed range (within $\pm 95 \%$ confidence limits) of $25-33.5{ }^{\circ} \mathrm{C} / \mathrm{km}$. The extrapolation of the fitted linear palaeotemperature profile to an assumed late Cenozoic surface temperature of around $10^{\circ} \mathrm{C}$ provides a maximum likelihood estimate of $1100 \mathrm{~m}$ of additional section subsequently eroded during late Cenozoic uplift (750 to $1600 \mathrm{~m}$ at $\pm 95 \%$ confidence limits). This is consistent with around $1000 \mathrm{~m}$ of post-Oligocene erosion identified on seismic sections. Results from other wells in the St. George's Channel basin are summarised in Figure 15.

In order to determine the thermal history of the basin margin, several samples were analysed from the Pembroke Peninsula, SW Wales, in the Lower Palaeozoic footwall of the Bala Fault (Fig. 16).

Although the Bala and St. George's Faults accommodated only relatively minor extension during the Triassic (Welch \& Turner 2000 contend that the bulk of the extension was accommodated by pureshear), major thickening of Jurassic sequences into the St. George’s Fault (Figs. 5, 7 \& 8) records its importance during renewed Jurassic extension. Consequently, we should expect thermal history data from the footwall to the St. George's Fault to preserve evidence of significant cooling in response to Jurassic footwall uplift. This would allow discrimination of the effects of erosion due to footwall uplift from that due to inversion and/or epeirogeny.

The fission track ages of apatite fission track samples GC399-18, 19 and 20 (locations in Fig. 15) are significantly younger than their Ordovician-Silurian stratigraphic ages (Fig. 16), suggesting they attained post-Silurian palaeotemperatures in excess of $110^{\circ} \mathrm{C}$ i.e. the total annealing temperature of apatite fission tracks. All three samples record protracted cooling histories defined by up to three discrete cooling episodes. For example, GC399-18 (central fission track age of 208.8 \pm 12.5 Ma.) cooled from maximum palaeotemperatures exceeding $110^{\circ} \mathrm{C}$ between $260-230$ Ma (Permo-Triassic extension). Assuming that palaeotemperatures during this early thermal episode were sufficient to anneal all fission tracks within the sample, two further discrete palaeothermal episodes can be inferred from the data. Following the first phase of total annealing, the sample was reheated to $85-100{ }^{\circ} \mathrm{C}$ between 195-130 Ma (Middle-Late Jurassic), inducing partial annealing of new tracks formed since 
the first heating episode. Subsequently, the sample cooled from a third heating episode, attaining 45$65^{\circ} \mathrm{C}$ between $70 \mathrm{Ma}$ and the present.

\section{Discussion}

\section{Geodynamics and kinematics of the inversion}

The absence of up to $2 \mathrm{~km}$ of Late Cretaceous post-rift rocks in the SGCB attests to major Late Cretaceous-Paleocene uplift (c.f. the Wealden Anticline where c.350 m Chalk was eroded during this period: Blundell 2002). An epeirogenic component to this uplift is suggested by the fact that these sequences are eroded from both basins and platforms. In common with other work on the western UK basins system (e.g. Brodie \& White 1995), igneous underplating is invoked as the principal mechanism driving the epeirogenic uplift. However, underplating does not account for the contractional fault reactivation documented here from the SGCB.

The susceptibility of the SGCB to Late Cretaceous-Paleocene inversion is highlighted by the roughly orthogonal relation between its principal bounding faults and the NW-oriented axis of early Alpine (Laramide) shortening (Hibsch et al. 1995). In contrast to the Laramide shortening, the kinematics of Eocene and Neogene phases of shortening was controlled by marked partitioning of strain between a predominant NW-oriented regional basement fault system (principally the Codling and Sticklepath lineaments), compartmentalized by NE-oriented faults within the SGCB itself (Fig. 17). Given the roughly N-S azimuth of later Alpine shortening (i.e. oblique to the trends of present structure; Hibsch et al. 1995), strain was accommodated by right-lateral strike-slip on the Codling and Sticklepath structures (c.f. Turner 1997), which both display a net right-lateral offset of some 5km (Holloway \& Chadwick 1986, Dobson \& Whittington 1979, Jenner 1981, Turner 1997). The imposition of NWoriented dextral shear on the SGCB led to counter-clockwise rotation of major fault blocks (Fig. 17). This highly noncoaxial strain is manifested as local transpression on right-stepping bends on the Bala and St. George's Faults, and small transtensional graben at left-stepping bends (e.g. Fig. 2iii, 2iv). Our model of left-lateral shear within an overall dextral shear couple is consistent with kinematic interpretations of post-Oligocene fault kinematics for eastern Ireland and the western Irish Sea (Cunningham et al. 2003, Parnell et al. 1988).

The history of inversion of the western UK basin system accords with the general picture emerging from the NW European foreland and its adjacent craton. The patchy distribution of inversion across NW Europe is accounted for by a model describing a heterogeneous mosaic of mainly Mesozoic extensional basins with strongly contrasting rheological characteristics. Subjected to a fairly uniform, NW-oriented compressional stress field, inversion was focused on discrete elements of this mosaic of former rift basins according to i) the orientation and frictional properties of their basin-bounding fault systems, and ii) their integrated lithospheric strength profiles (e.g. Kusznir \& Park 1987, Sandiford 
1999, Nielsen \& Hansen 2000, van Wees \& Beekman 2000). In the case of the SGCB, the noncoaxial orientation of its principal faults with respect to the syn-inversion stress field appears to have been outweighed by their low frictional coefficients and/or the low effective stress acting across them (due, for example, to high pore fluid pressure). In terms of rheological heterogeneity, the maps of Ziegler et al. (1995) illustrate the late Mesozoic-Cenozoic SGCB sandwiched between the stable Palaeozoic Welsh and Irish massifs. Thus, the relative weakness of the relatively young SGCB meant that it served to focus strain during Late-Mesozoic-Cenozoic shortening.

\section{Contribution of inversion to regional exhumation}

Despite the unique insight they can provide, both thermal history data and sonic velocity analyses are potentially ambiguous: i) thermal history data are susceptible to transient heating episodes where thermal proxies like apatite fission tracks and vitrinite reflectance are significantly elevated without concomitant increases in burial depth, and ii) the reliance of sonic velocities on the mechanical compaction behaviour of buried rock successions means that interpretation of these data can be similarly complicated where rock successions exhibit abnormal mechanical behaviour (e.g. pore fluid overpressure, lithological heterogeneity, locally cemented zones). Of key importance, therefore, is the consistency of independent interpretations of thermal history and sonic velocity data because this represents an effective test of their mutual reliability as exhumation proxies.

Our interpretations of thermal history and sonic velocity datasets from the SGCB show general consistency both with each other and with data from the surrounding region (Corcoran \& Clayton 1999, Lewis et al. 1992, Menpes \& Hillis 1995, Murdoch et al. 1995, Rowley \& White 1998, Ware \& Turner 2002). For example, thermal history and sonic velocity data from the main depocentre of the SGCB point to c. $1 \mathrm{~km}$ of exhumation during the Neogene, which is in good agreement with recent estimates of Neogene exhumation across the contiguous Central Irish Sea and East Irish Sea basins (e.g. Green et al. 2001; Ware \& Turner 2002). Exhumation estimates from sonic velocities within the Mercia Mudstone Formation of exploration wells from the Central Irish Sea basin are somewhat higher $(<2.25 \mathrm{~km})$ than the estimates from the SGCB. On the basis of apatite fission track and vitrinite reflectance data, Green et al. (2001) suggested that Triassic units within the Central Irish Sea basin reached their maximum burial depths (and hence post-depositional palaeotemperatures) prior to a phase of exhumation in the early Cretaceous which removed up to $3 \mathrm{~km}$ of sediments from this basin. It is therefore probable that the exhumation estimates based on sonic velocity data from the NW of the SGCB record the early Cretaceous exhumation episode (c.f. Holford et al. in press) THIS IS NOT REFERENCED !. The idea of multiple phases of post-Palaeozoic exhumation across this region is corroborated by apatite fission track data from onshore Pembrokeshire, which provide further 
evidence for distinct phases of exhumation-related cooling during the Cretaceous and Cenozoic (Fig. 16).

The nature of the geodynamic processes that drove the initial uplift is an outstanding problem. The complex exhumation pattern of much of Britain results largely from the interference of uplift related to the Cretaceous-Palaeogene opening of the North Atlantic and multiple inversion episodes that began in the Cretaceous. It is maximal over the submergent East Irish Sea basin, some $500 \mathrm{~km}$ from the Atlantic margin, where Late Mesozoic-Cenozoic uplift was responsible for the erosion of up to three kilometres of the cover (Lewis et al. 1992). This complexity of UK exhumation is consistent with the patchy distribution of Cenozoic uplift illustrated by the palaeogeographic maps of Coward et al. (2003). They show Palaeogene and Neogene inversion axes located along the length of the NW European Atlantic margins, as well as the better known ones in southern Britain and the English Channel. Whilst it is not uncommon for orogenic stress to be transmitted very large distances through foreland cratons (Alpine compression inverted basins up to $1600 \mathrm{~km}$ north of the Alpine belt: Ziegler 1989), Bott (1993) models horizontal compressive stress of up to 100 MPa generated by prominent oceanic ridges underlain by anomalously hot, buoyant mantle. Consequently, these more distal inversion axes are interpreted to have formed in response to plume-enhanced ridge-push forces generated during the Oligocene and Neogene opening of the eastern arm of the North Atlantic (c.f. Lundin \& Dore 2002).

Brodie \& White (1995) argue that observed shortening in the East Irish Sea basin, to the north of this study area, is significantly less than the c. $30 \%$ strain that they contend would be required to account for three kilometres exhumation. Instead, they invoke basaltic underplating as the principal mechanism driving the exhumation. However, the existence of up to 8km thickness of underplated basalt beneath the EISB is reliant on evidence from modelling wide-angle seismic data at the limit of its resolution (Al-Kindi et al. 2003). Moreover, across much of the western UK the absence of evidence for substantial inversion is not evidence of its absence. Measurement of inversion-related shortening strain in exhumed basins is problematic because:

i) Fault heaves in inverted basins are apparent and, therefore, not a good record of horizontal shortening (Turner \& Williams 2004).

ii) Given that inversion geometries are most pronounced in the shallow parts of inverted basins where reverse fault displacement is greatest, the evidence for inversion is largely obliterated in relatively deeply exhumed basins like the East Irish Sea.

iii) In fine-grained siliciclastic basinfills like the SGCB, a significant component of inversion-related shortening may be accommodated by 'pure shear' - homogeneously distributed strain mechanisms such as porosity reduction and vertical thickening (c.f. Eisenstadt \& Withjack 1995). 
Our favoured model to account for the exhumation of the western UK region is derived from that of Ware \& Turner (2002) from the EISB. Based on analysis of sonic velocity profiles, they identified short-wavelength variations in exhumation magnitude, with marked contrast in exhumation often occurring across individual faults. This pattern is interpreted in terms of intra-basin variations in inversion-related shortening superimposed on more uniform, epeirogenic exhumation attributed to magmatic underplating. From our mapping in the SGCB, it has been demonstrated that inversion accommodated significant shortening of at least 20\% (from line-length restoration of the cross-section across the St. Tudwal's Arch: Fig. 5). The contrasting geological history and geodynamic setting of individual elements of the western UK basins mean that we should be cautious about extrapolating our estimates of inversion-related shortening from the SGCB throughout the Irish Sea basins. Nonetheless, it is clear that the bulk strain generated by inversion of basins like the SGCB is sufficiently large to have contributed significantly to regional exhumation.

\section{Conclusions}

- The St. George's Channel basin (SGCB) forms a part of the exhumed western UK basin system in which multiple episodes of post-Triassic uplift led to erosion of up to $3 \mathrm{~km}$ of the Mesozoic-Cenozoic overburden.

- In the SGCB, exhumation varied between at least $1.0 \mathrm{~km}$ in the centre and $2.24 \mathrm{~km}$ at its margins.

- Tectonic inversion - the shortening and reactivation of formerly extensional basins - was the dominant mechanism of uplift driving the exhumation of the SGCB.

- Unravelling the exhumation history of the SGCB and contiguous basins is complicated because of the superimposed effects of igneous underplating and inversion episodes during i) the Late Cretaceous-Paleocene and ii) the Neogene.

- Neogene inversion was highly noncoaxial, with transpression focused at restraining bends and stepovers on major faults.

- The evidence for tectonic inversion in exhumed basins may often be cryptic because i) erosion of the shallower segments of reactivated faults, where reverse offsets are most pronounced, and ii) if the compressional stress field is noncoaxial with respect to the trends of extant lineaments, the resultant transpressional strain may be highly localized.

\section{Acknowledgements}

JPT and GAW thank Andrew Harding for first showing them around the subsurface in the St. George’s Channel basin. Paul Green of Geotrack International has supported our efforts in all aspects 
of thermal history analysis. GAW and SPH worked on the St. George's Channel basin as part of their $\mathrm{PhD}$ projects for which we acknowledge the financial support of the Natural Environment Research Council, the British Geological Survey and Enterprise Oil (now Shell). We are grateful to Seismic Micro-Technology for free provision of their Kingdom Suite seismic interpretation and mapping software.

\section{Figure captions}

Fig. 1. Free-air gravity anomaly of the St. George's Channel basin and surrounding region. The gravity data are a compilation of ship track and satellite measurements sampled and gridded with $1 \mathrm{~km}$ cell spacing. Principal fault traces mapped from the seismic data are superimposed as solid black lines. Broken lines represent inferred and extrapolated fault traces based on limited seismic coverage. Locations of wells and seismic profiles used in this paper are also highlighted. Inset shows the configuration of the c. $3000 \mathrm{~km}^{2}$ grid of $142 \mathrm{NW}$-oriented (dip-parallel) reflection seismic profiles tied by $58 \mathrm{NE}$-oriented profiles used in this study. It is assembled from three 2D surveys acquired between 1983 and 1996 comprising migrated, multichannel data owned by ChevronTexaco (formerly Chevron), BP (formerly Arco) and WesternGeco (formerly Western Geophysical). The location of this area within Western Europe is shown in Figure 3.

Key - BF: Bala Fault; CF: Codling Fault; NWFF: Northwest Flank Fault; SF: Sticklepath Fault; SGF: St. George’s Fault.

Fig. 2. Structural contours at basal Triassic (i), top Triassic (ii), basal Cenozoic (iii) and intra-Eocene (iv) levels. Contours are in two-way travel time; fault traces are shaded black. Also shown are well locations and the position of the seismic profiles in Figures 6-8 and 10. Note the coincidence of structural culminations with right-stepping bends on the main NE-trending fault systems, a consequence of their reactivation in left-lateral shear during Neogene basin inversion.

Fig. 3. Location of the St. George's Channel basin in relation to major regional fault systems. Fault traces are from Ziegler et al. (1995), Lefort \& Agarwal (2000) and Turner (1997); the depocentre of the St. George's Channel basin is shaded grey. The boxed area is shown in more detail in Figure 1. Key - AF: Anton-Dohrn Fault; CF: Codling Fault; DF: Dolus Fault; FP: Fastnet-Porcupine Fault; KF: Kerfone Fault; QVF: Quessoy-Vallet Fault; SF: Sticklepath Fault.

Fig. 4. Seismic-stratigraphic framework for the St. George's Channel basin. Also shown is the stratigraphic position of horizons whose subsurface structure is given in the maps in Figure 2. 
Fig. 5. Cross-section from the St. George's Channel basin to the Central Irish Sea basin, through the St. Tudwal's arch (offshore Llyn Peninsula). It exemplifies the inversion of relief that often accompanies basin inversion, with pronounced thickening of the Lower Jurassic succession toward what is now an uplifted structural culmination. Location of the line is given in Figure 1. The boxes give the approximate positions, with respect to this cross-section, of the seismic profiles in Figures 6 and 8.

Fig. 6. Seismic profile through the NW flank of the St. George's Channel basin showing detail in the boxed area indicated in Figure 5 (location of this line is given in Figure 2). This margin of the basin was uplifted in response to reactivation of the Northwest Flank Fault during Late CretaceousPaleocene and Neogene inversion.

Fig. 7. Seismic profile and interpretation through the St. George's and Bala Fault systems, SE margin of the St. George's Channel basin. The structure is dominated by a Mesozoic rollover anticline, the Morfa structure, subsequently tightened during Late Cretaceous-Paleocene and/or Neogene inversion. Location of the line is given in Figure 2.

Fig. 8. Seismic profile and interpretation through a severely reactivated segment of the Bala Fault, SE margin of the St. George's Channel basin. Shortening is accommodated by reverse displacement along the low-angle Bala Fault and consequent steepening of the forelimb of the Morfa rollover anticline. The buttressing effect of a ramp on the Bala Fault arrested reverse displacement with further shortening accommodated by the formation of a NW-directed thrust splaying from the Bala Fault. Location of the line is given in Figure 2.

Fig. 9. Strike-parallel seismic profile and interpretation through a listric fault splaying from a jog in the St. George's Fault (location given in Figure 2). Note the reversal in the sense of thickening of synkinematic Jurassic and Eocene sequences. Earlier transtension is recorded by a thicker Jurassic succession in the hanging wall of the fault. Later transpression reactivated the fault, with the Eocene succession displaying preferential thickening in its footwall.

Fig. 10. Seismic profile and interpretation through a small Cenozoic extensional basin containing a synkinematic sequence of Late Eocene-Oligocene age. The basal Cenozoic and intra-Eocene maps in Figure 2 show that the extensional fault bounding the SE margin of this basin is one of an array of enechelon structures. They are interpreted as Riedel shears that formed at a transtensional jog on the StGeorge's-Bala Fault system in response to their reactivation in left-lateral shear during Neogene basin inversion. 
Fig. 11. Graph showing interval transit time (ITT) vs. midpoint depth $\left(d_{m}\right)$ for the Triassic Mercia Mudstone Formation for 15 wells in the study area. Given that sonic velocities provide a record of maximum burial depth, the vertical difference between ITT vs. $d_{m}$ of a well yields a measure of the magnitude of the burial anomaly i.e. exhumation normalized to that of the reference wells.

Fig. 12. Apparent exhumation estimates spanning the St. George's Channel and South Celtic Sea basins determined using data from sonic velocity logs. The diameter of each circle is proportional to the magnitude of the burial anomaly, i.e. the magnitude of apparent exhumation.

Fig. 13. (a) Palaeotemperature profile derived from apatite fission track and vitrinite reflectance data from well 106/24a-2b. Open circles show corrected bottom hole temperature values; filled circles show vitrinite reflectance-derived palaeotemperatures; horizontal bars and arrows denote palaeotemperatures modelled from apatite fission track analysis. The vitrinite reflectance and apatite fission track data define an approximately linear late Cenozoic palaeogeothermal gradient comparable to that of the present day. This suggests that the elevated maximum palaeotemperatures recorded by the thermal history data are a consequence of their deeper burial prior to Neogene exhumation. (b) Maximum liklihood estimate of additional section eroded during Cenozoic uplift.

Fig. 14. Measured vitrinite reflectance $\left(\% \mathrm{R}_{0}\right)$ vs. depth plots for two wells from the St. George's Channel basin. The continuity of the $\% \mathrm{R}_{0}$ trend across the basal Cenozoic unconformity indicates that the succession attained its maximum burial depth subsequent to the formation of the unconformity.

Fig. 15.rosion estimates for wells in the St. George's Channel basin derived from thermal history reconstruction. Estimates of missing section from sonic velocity analysis are shown adjacent to each well. Also shown are contour plots describing the optimum thermal history for 5 wells. Contoured banana-shaped regions define the allowed ranges (within $\pm 95 \%$ confidence limits) of palaeogeothermal gradients and thicknesses of eroded section that are consistent with the Neogene palaeotemperatures modelled from the vitrinite reflectance and apatite fission track data. Black dots indicate the maximum likelihood estimates for each well. The location of apatite samples collected from onshore SW Wales (see Fig. 16) are shown as solid circles.

Fig. 16. Timing of cooling episodes for a series of apatite samples collected from onshore SW Wales (sample locations given in Fig. 15), based on thermal history interpretation of apatite fission track data. Shaded horizontal bars represent estimates (within 95\% confidence limits) of the time at which individual samples began to cool from palaeotemperature peaks. Vertical bars correspond to the time ranges which are consistent for each sample. In this case, three distinct cooling episodes are recognised, beginning during the late Permian-early Triassic (260-230 Ma), Jurassic-early Cretaceous (195-130 Ma) and late Cretaceous-Cenozoic (70-0 Ma). 
Fig. 17. Kinematics of the Neogene inversion of the St. George's Channel basin. North-south shortening imposed a right-lateral shear couple on the principal NW-oriented basement lineaments (e.g. Codling Fault, Sticklepath Fault and its splays, various lineaments picked out by the free-air gravity anomaly). Clockwise rotation within this shear couple was accommodated by reactivation of the Bala, St. George's, and Northwest Flank faults in left-lateral shear.

\section{References}

Al-Kindi, S., White, N., Sinha, M., England, R. \& Tiley, R. 2003. Crustal trace of a hot convective sheet. Geology, 31, 207-211.

Athy, L.F. 1930. Density, porosity and compaction of sedimentary rocks. Bulletin American Association of Petroleum Geologists, 14, 1-24.

Blundell et al. 1972. J. Geol Soc. 127, 339-375

Blundell, D.J. 2002. Cenozoic inversion and uplift of southern Britain. In: Doré, A.G., Cartwright, J.A., Stoker, M.S., Turner, J.P. \& White, N. (eds) Exhumation of the North Atlantic Margin: Timing, Mechanisms and Implications for Petroleum Exploration. Geological Society, London, Special Publications, 196, 85-101.

Bray, R.J., Green, P.F. \& Duddy, I.R. 1992. Thermal history reconstruction using apatite fission track analysis and vitrinite reflectance: a case study from the UK East Midlands and Southern North Sea. In: Hardman, R. F. P. (ed) Exploration Britain: Geological insights for the next decade. Geological Society, Special Publication, 67, 3-25.

Bott, M.H.P. 1993. Modelling the plate-driving mechanism. Journal of the Geological Society of London, 150, 941-953.

Brodie, J. \& White, N. 1995. The link between sedimentary basin inversion and igneous underplating. In: Buchanan, J.G. \& Buchanan, P.G. (eds) Basin Inversion. Geological Society, Special Publication, 88, 21-38.

Burnham, A.K. \& Sweeney, J.J. 1989. A chemical kinetic model of vitrinite maturation and reflectance. Geochimica et Cosmochimica Acta, 53, 2649-2657. 
Cope, J.C.W. 1998. The Mesozoic and Tertiary history of the Irish Sea. In: Meadows, N.S., Trueblood, S.P., Hardman, M. \& Cowan, G. (eds) Petroleum Geology of the Irish Sea and Adjacent Areas. Geological Society, Special Publication, 124, 47-59.

Corcoran, D. \& Clayton, G. 1999. Interpretation of vitrinite reflectance profiles in the Central Irish Sea area: implications for the timing of organic maturation. Journal of Petroleum Geology, 22, 261286.

Coward, M.P. 1994. Inversion Tectonics. In: Hancock, P.L. (ed) Continental Deformation. Pergamon Press, Oxford, 289-304.

Coward, M.P., Dewey, J.F., Hempton, M. \& Holroyd, J. 2003. Tectonic evolution. In: Evans, D., Graham, C., Armour, A. \& Bathurst, P. (eds) The Millennium Atlas: petroleum geology of the central and northern North Sea. Geological Society, 17-33.

Cunningham, M.J.M., Densmore, A.L., Allen, P.A., Phillips, W.E.A., Bennett, S.D., Gallagher, K. \& Carter, A. 2003.Evidence for post-early Eocene tectonic activity in southeastern Ireland. Geological Magazine, 140, 101-118.

Dobson, M.R. \& Whittington, R.J. 1979. The Geology of the Kish Bank Basin. Journal of the Geological Society, 136, 243-249.

Dobson, M.R. \& Whittington, R.J. 1987. The Geology of Cardigan Bay. Proceedings of the Geologists Association, 98, 331-353.

Doré, A.G. \& Jensen, L. N. 1996. The impact of late Cenozoic uplift and erosion on hydrocarbon exploration: offshore Norway and some other uplifted basins. Global and Planetary Change, 12, 415436. Replace with Dore et al. 2002 Geol. Soc. Exhumation Volume

Eisenstadt, G. \& Withjack, M.O. 1995. Estimating inversion: results from clay models. In: Buchanan, J.G. \& Buchanan, P.G. (eds) Basin Inversion. Geological Society, Special Publication, 88, 39-57.

Gallagher, K., Brown, R. \& Johnson, C. 1998. Fission track analysis and its application to geological problems. Annual Review of Earth and Planetary Sciences, 26, 519-572.

Green, P.F., Duddy, I.R. \& Bray, R. J. 1995. Applications of thermal history reconstruction in inverted basins. In: Buchanan, J.G. \& Buchanan, P.G. (eds) Basin Inversion. Geological Society, 
Special Publication, 88, 149-167.

Green, P.F., Duddy, I.R., Bray, R.J., Duncan, W.I. \& Corcoran, D.V. 2001. The influence of thermal history on hydrocarbon prospectivity in the Central Irish Sea Basin. In Shannon, P.M., Haughton, P.D.W. \& Corcoran, D.V. (eds) The Petroleum Exploration of Ireland's Offshore Basins. Geological Society, London, Special Publications, 188, 171-188.

Green, P.F., Duddy, I.R. \& Hegarty, K.A. 2002. Quantifying exhumation in sedimentary basins of the UK from apatite fission track analysis and vitrinite reflectance data: precision, accuracy and latest results. In: Doré, A.G., Cartwright, J.A., Stoker, M.S., Turner, J.P. \& White, N. (eds) Exhumation of the North Atlantic Margin: Timing, Mechanisms and Implications for Petroleum Exploration. Geological Society, London, Special Publications, 196, 331-354.

Heasler, H.P. \& Kharitonova, N.A. 1996. Analysis of Sonic Well Logs Applied to Erosion Estimates in the Bighorn Basin, Wyoming. Bulletin American Association of Petroleum Geologists, 80(5), 630646.

Hibsch, C., Jarrige, J.J., Cushing, E.M. \& Mercier, J. 1995. Palaeostress analysis, a contribution to the understanding of basin tectonics and godynamic evolution. Example of the Permian/ Cenozoic tectonics of Great Britain and godynamic implications in western Europe. Tectonophysics, 252, 103136.

Hillis, R. R. 1995. Regional Tertiary exhumation in and around the United Kingdom. In: Buchanan, J.G. \& Buchanan, P.G.(eds) Basin Inversion. Geological Society, Special Publication, 88, 167-191. Holford et al.

Holloway, S. \& Chadwick, R.A. 1986. The Sticklepath-Lustleigh fault zone: Cenozoic sinistral reactivation of a Variscan dextral strike-slip fault. Journal of the Geological Society, 143, 447-452.

Issler, D.R. 1992. A new approach to shale compaction and stratigraphic restoration, BeaufortMackenzie Basin and Mackenzie corridor, Northern Canada. AAPG Bulletin, 76, 1170-1189.

Japsen, P. 1998. Regional velocity-depth anomalies, North Sea Chalk: a record of overpressure and Neogene uplift and erosion. AAPG Bulletin, 82, 2031-2074.

Jenner, J.K. 1981. The Structure and Stratigraphy of the Kish Bank Basin. In: Illing, L.V. \& Hobson, G.D. (eds) Petroleum Geology of the Continental Shelf of North-West Europe, Institute of Petroleum, London. 426-431. 
Kusznir, N.J. \& Park, R.G. 1987. The extensional strength of the continental lithosphere: its dependence on geothermal gradient and crustal thickness. In: Coward, M.P., Dewey, J.F. \& Hancock, P.L. (eds) Continental Extensional Tectonics. Geological Society, Special Publication, 28, 35-52.

Lefort, J.P. \& Agarwal, B.N.P. 2000. Gravity and geomorphological evidence for a large crustal bulge cutting across Brittany (France): a tectonic response to the closure of the Bay of Biscay. Tectonophysics, 323, 149-162.

Lewis, C.L.E., Green, P.F., Carter, A. \& Hurford, A.J. 1992. Elevated K/T Paleotemperatures Throughout Northwest England - 3 Kilometers of Cenozoic Erosion? Earth and Planetary Science Letters, 112, 131-145.

Lundin, E. \& Dore, A. G. 2002. Mid-Cenozoic post-breakup deformation in the 'passive' margins bordering the Norweigian-Greenland Sea. Marine and Petroleum Geology, 19, 79-93.

Magara, K. 1976. Thickness of removed sedimentary rocks, paleopore pressure and palaeotemperature, southwestern part of Western Canada basin. AAPG Bulletin, 60, 554-566.

Menpes, R.J. \& Hillis, R.R. 1995. Quantification of Cenozoic exhumation from sonic velocity data, Celtic Sea/South-Western Approaches. In: Buchanan, J.G. \& Buchanan, P.G. (eds) Basin Inversion. Geological Society, Special Publication, 88, 191-207.

Murdoch, L. M., Musgrove, F. W. \& Perry, J. S. 1995. Tertiary uplift and inversion history in the North Celtic Sea basin and its influence on source rock maturity. In: Croker, P. F. \& Shannon, P. M. (eds) The Petroleum Geology of Ireland’s Offshore Basins. Geological Society, Special Publication, 93, 297-319.

Nielsen, S.B. \& Hansen, D.L. 2000. Physical explanation of the formation and evolution of inversion zones and marginal troughs. Geology, 28, 875-878.

Parnell, J., Shukla, B. \& Meighan, I.G. 1988. The lignite and associated sediments of the Tertiary Lough Neagh Basin. Irish Journal of Earth Science, 10, 67-88.

Rowley, E. \& White, N. 1998. Inverse Modelling of Extension and Exhumation in the East Irish Sea and Surrounding Areas. Earth and Planetary Science Letters, 161, 57-71. 
Sandiford, M. 1999. Mechanics of basin inversion. Tectonophysics, 305, 109-120.

Tappin, D.R., Chadwick, R.A., Jackson, A.A., Wingfield, R.T.R. \& Smith, N.J.P. 1994. United Kingdom offshore regional report: The geology of Cardigan Bay and the Bristol Channel. London: HMSO for the British Geological Survey.

Turner, J.P. 1996. Gravity-driven nappes and their relation to palaeobathymetry: examples from West Africa and Cardigan Bay, UK. In: Buchanan, P.G. \& Nieuwland, D. A. (eds) Modern Developments in Structural Interpretation, Validation and Modelling. Geological Society, Special Publication, 99, 345-362.

Turner, J.P. 1997. Strike-slip fault reactivation in the Cardigan Bay basin. Journal of the Geological Society, 154, 5-8.

Turner, J.P. \& Williams, G.A. 2004. Sedimentary basin inversion and intra-plate shortening. EarthScience Reviews.

van Wees, J.D. \& Beekman, F. 2000. Lithosphere rheology during intraplate basin extension and inversion: inferences from automated modelling of four basins on western Europe. Tectonophysics, 320, 219-242.

Ware, P.D. \& Turner, J.P. 2002. Sonic velocity analysis of the Cenozoic exhumation of the Irish Sea basin. In: Doré, A.G., Cartwright, J.A., Stoker, M.S., Turner, J.P. \& White, N. (eds) Exhumation of the North Atlantic margin: timing, mechanisms and implications for petroleum exploration. Geological Society, Special Publication, 196, 355-371.

Welch, M.J. \& Turner, J.P. 2000. Triassic-Jurassic development of the St. George’s Channel basin, offshore Wales, UK. Marine and Petroleum Geology, 17(6), 723-750.

Ziegler, P.A. 1989. Evolution of the North Atlantic - An Overview. In: Tankard, A. J. \& Balkwill, H. J. (eds) Extensional Tectonics and Stratigraphy of the North Atlantic Margins. American Association of Petroleum Geologists Memoirs, 46, 471-500.

Ziegler, P.A., Cloetingh, S. \& van Wees, J.D. 1995. Dynamics of intra-plate compressional deformation: the Alpine foreland and other examples. Tectonophysics, 252, 7-59. 


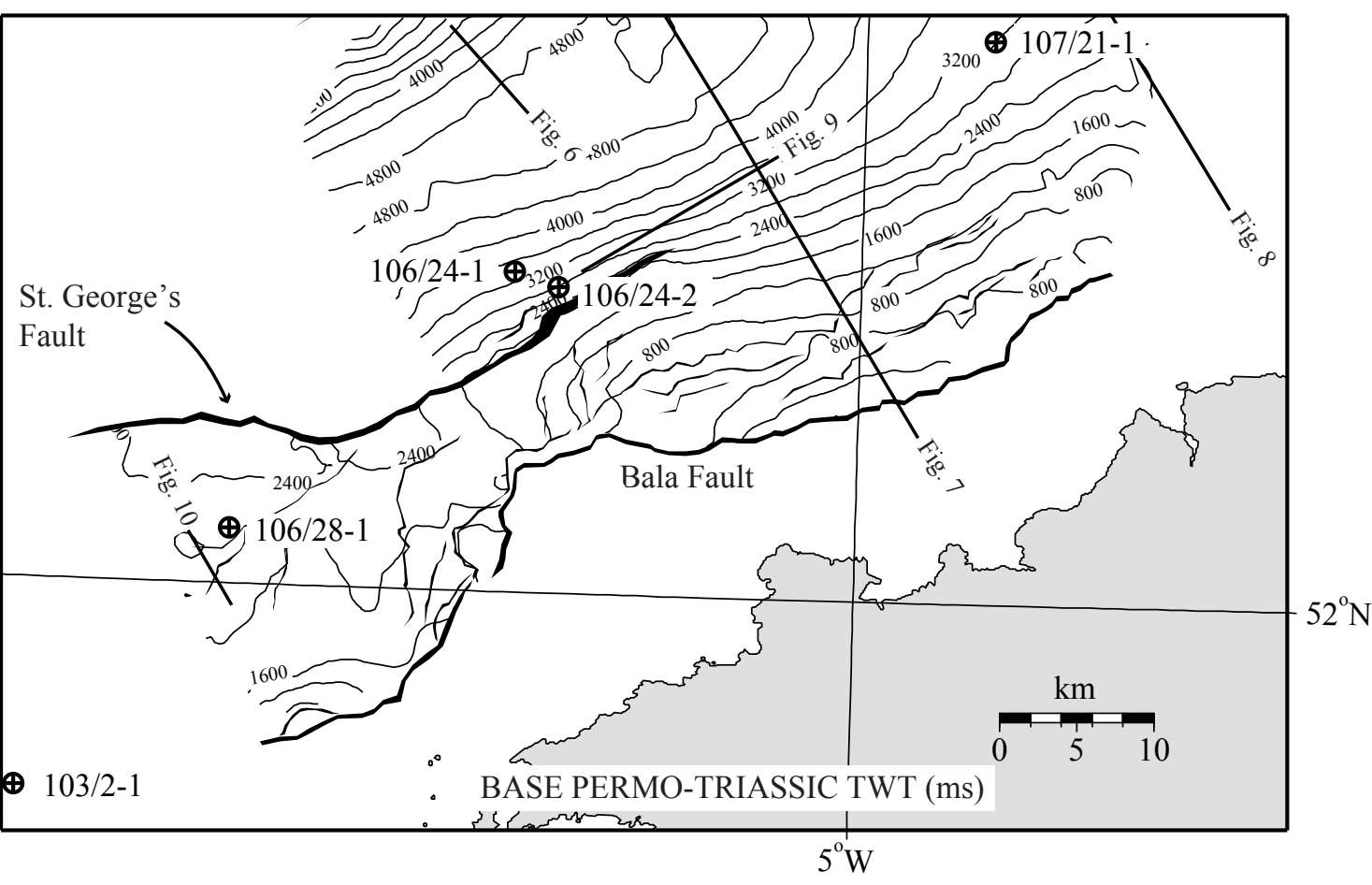

Fig. $2 \mathrm{i}$ 


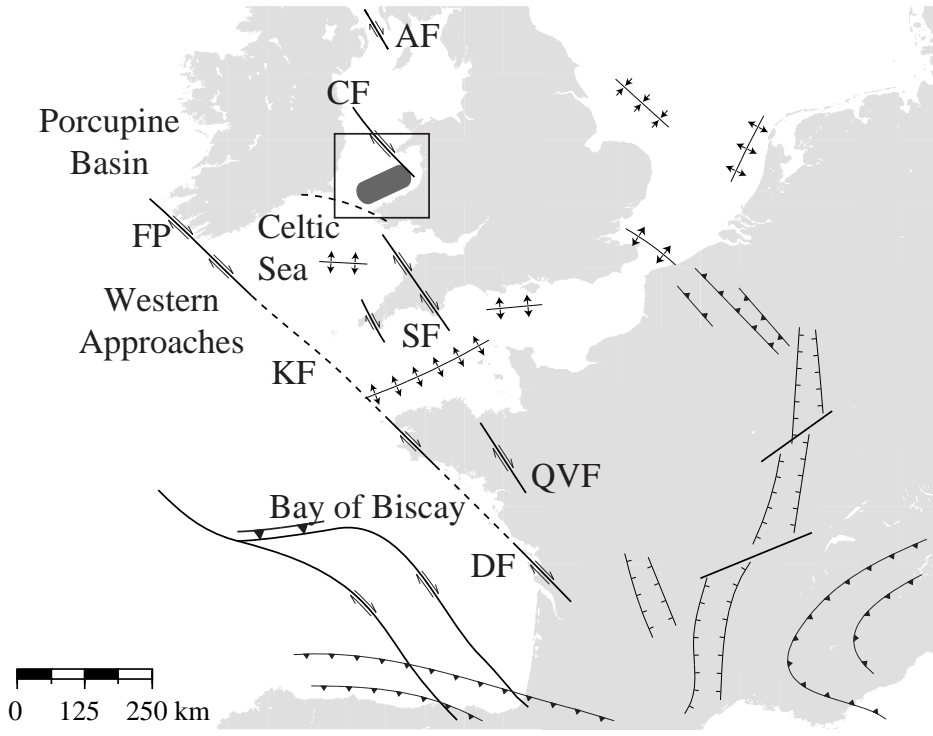

Fig. 3 


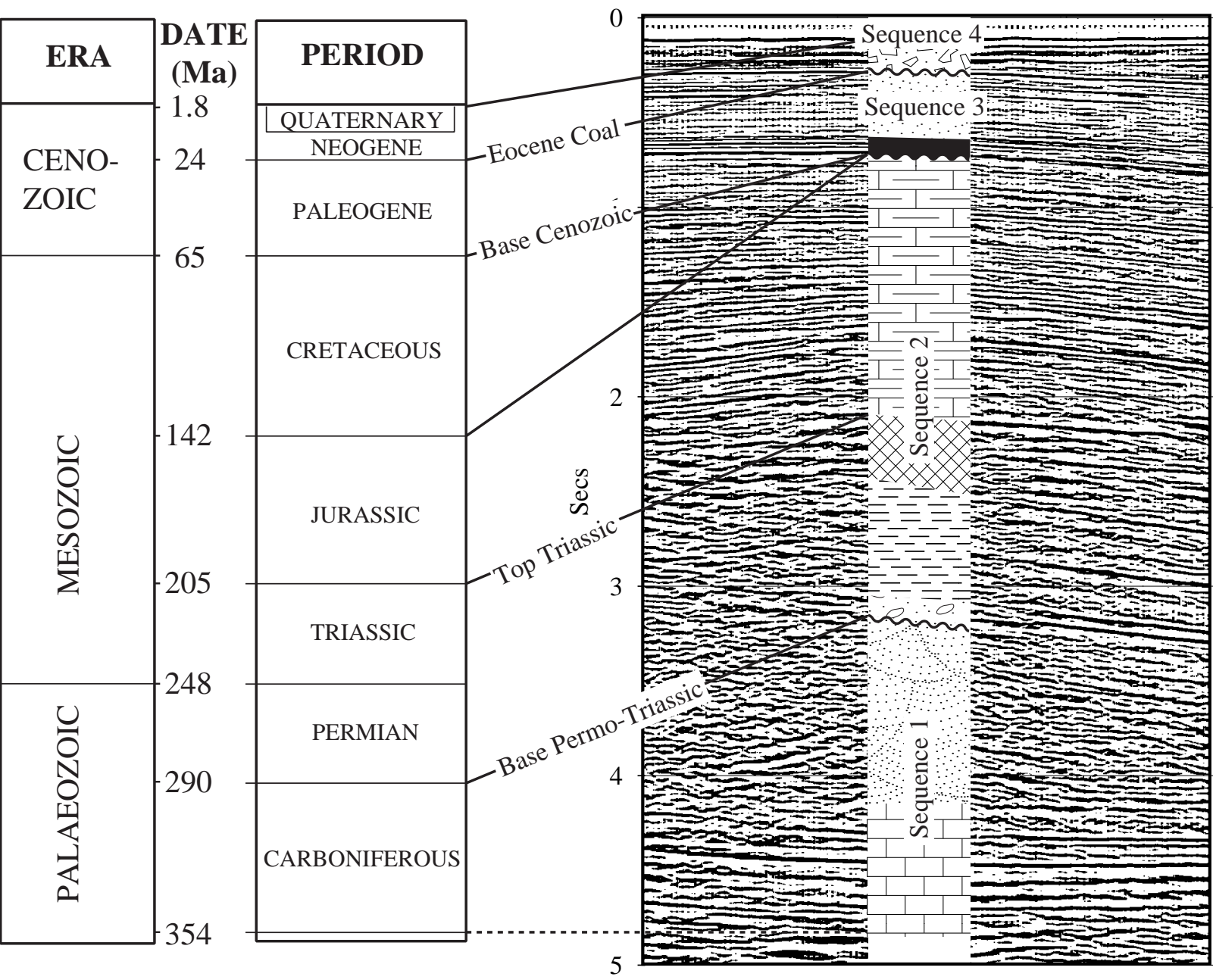


Central Irish Sea Basin

$\overbrace{}^{\frac{\Xi}{\Xi}} 2$

Irish Sea Geanticline
St. Tudwal's Arch

(Llyn Peninsula)
St. George's Channel Basin

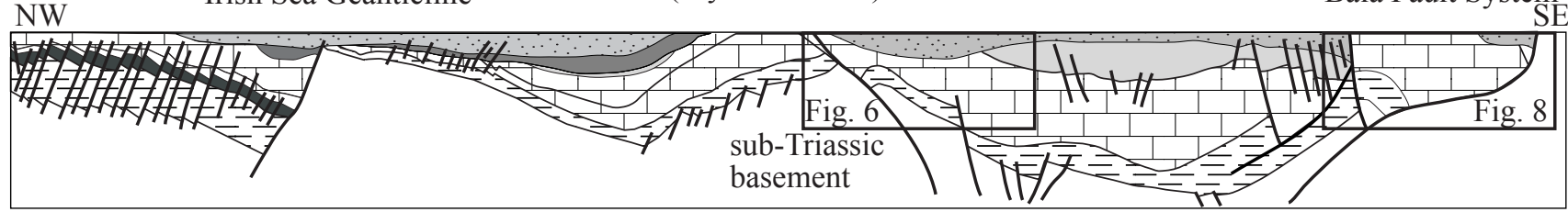

Neogene

Paleogene

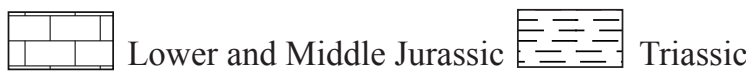

Fig. 5 

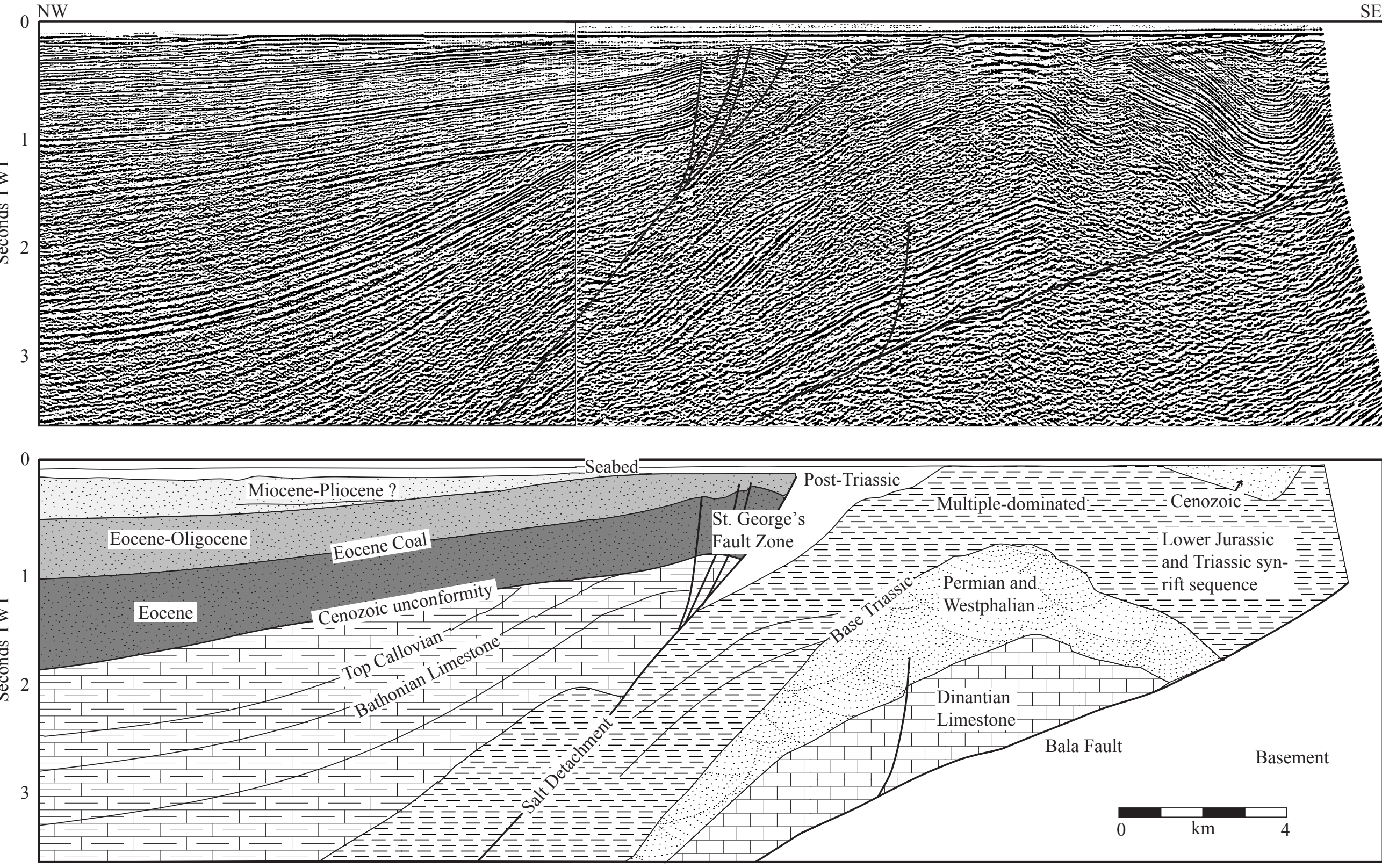


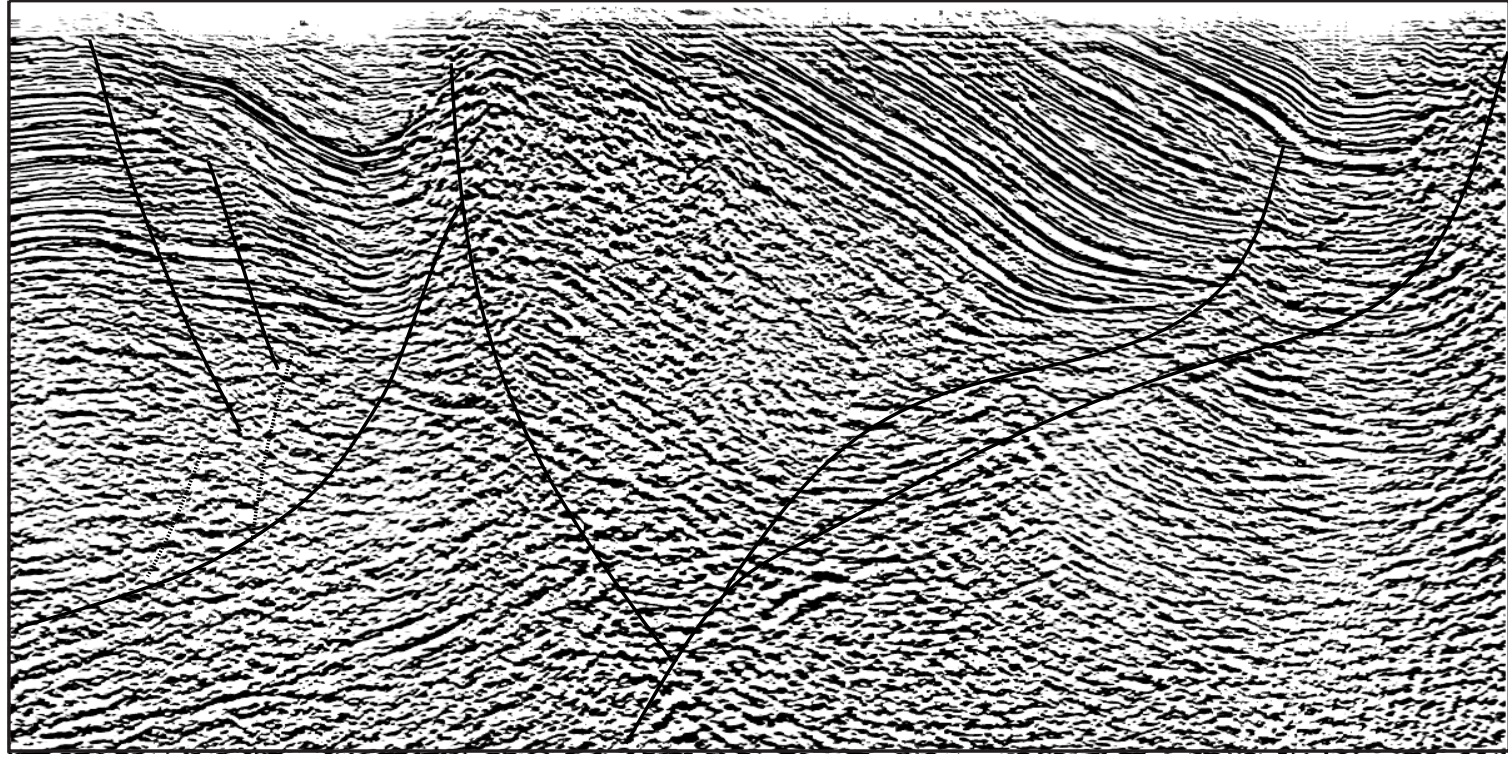

0

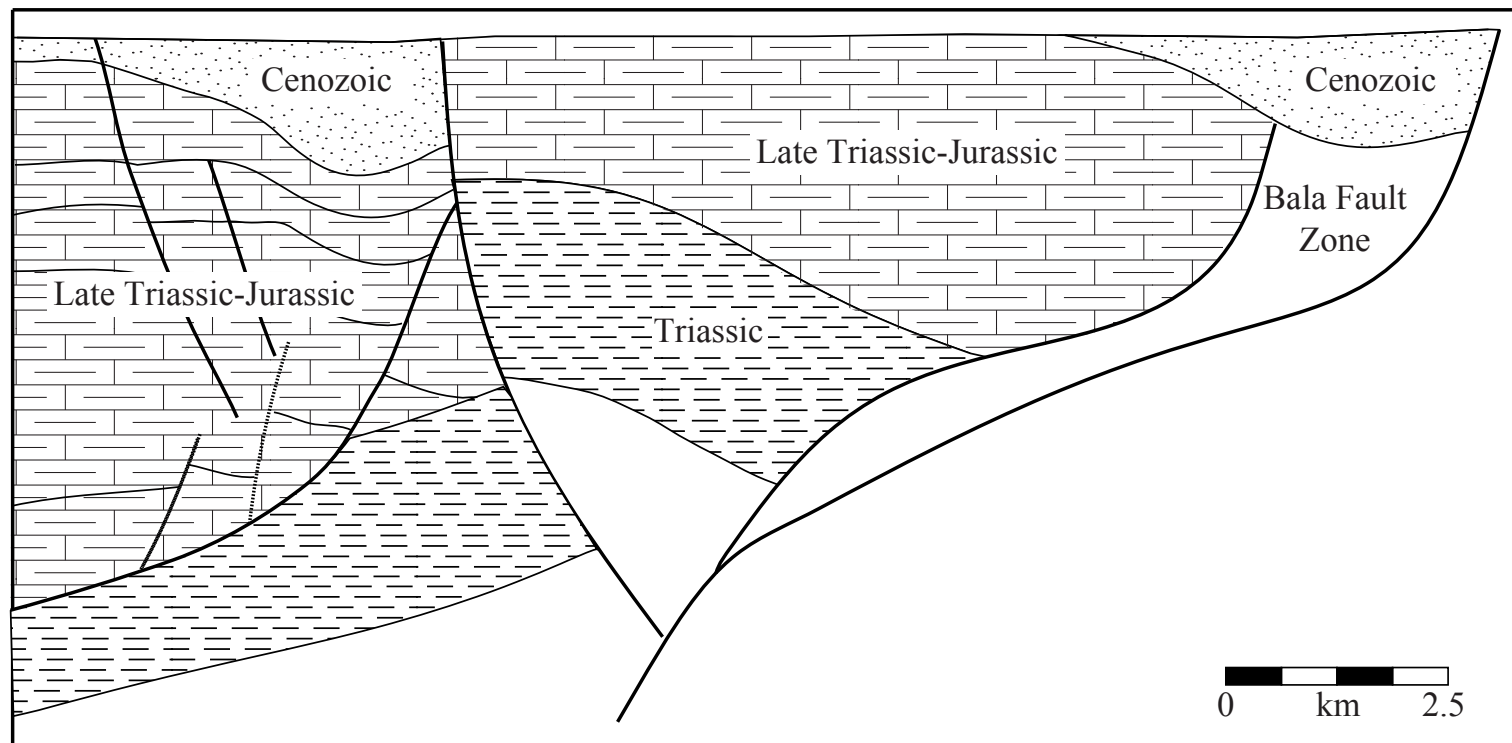

Fig.8 


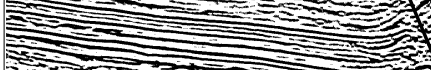

NOND,

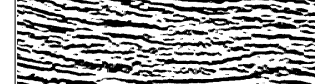

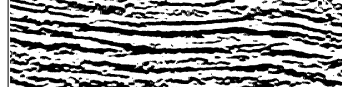

ind

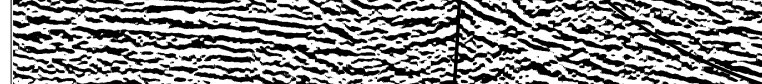

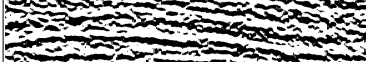

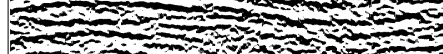
$\rightarrow-2$ in

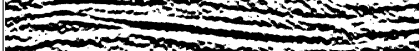
作

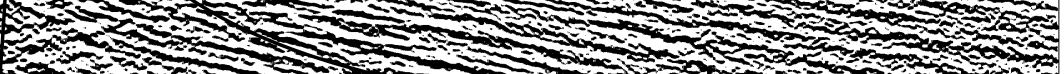

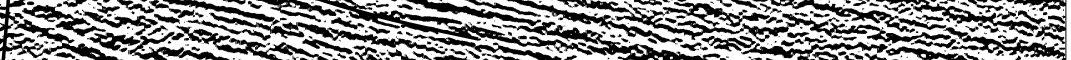

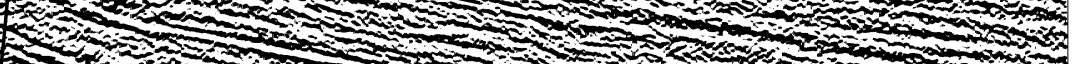
$x_{2}$

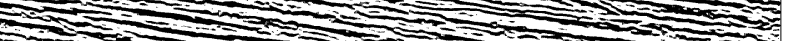

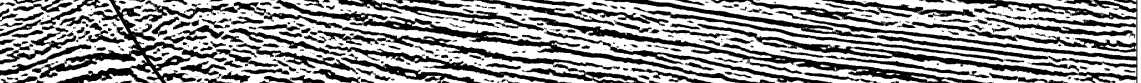

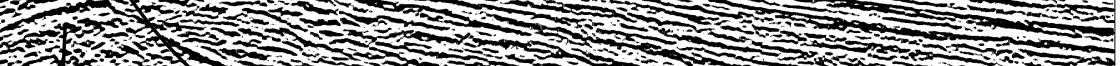
( N

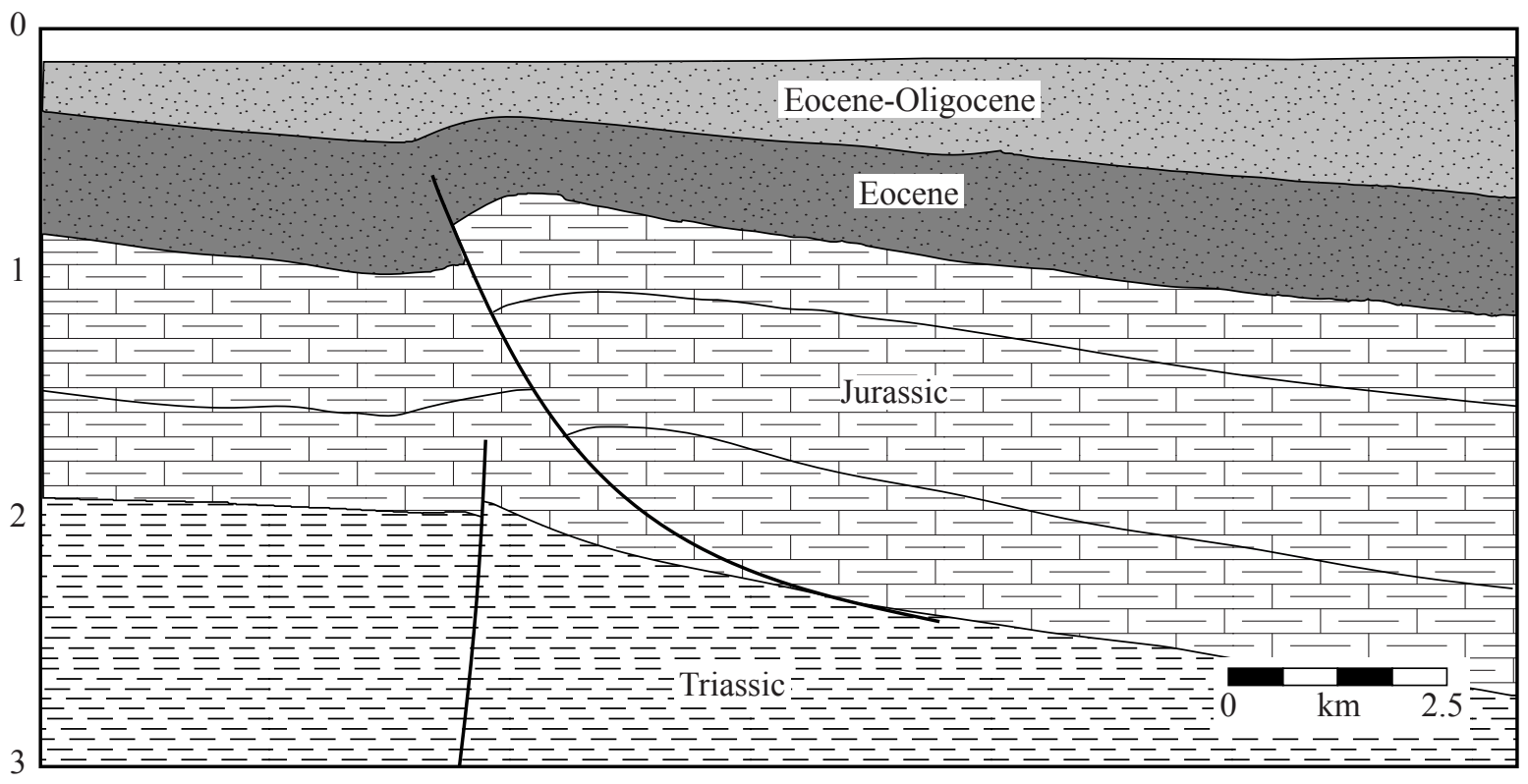

Fig. 9 
$\therefore$

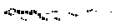

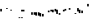

- 1

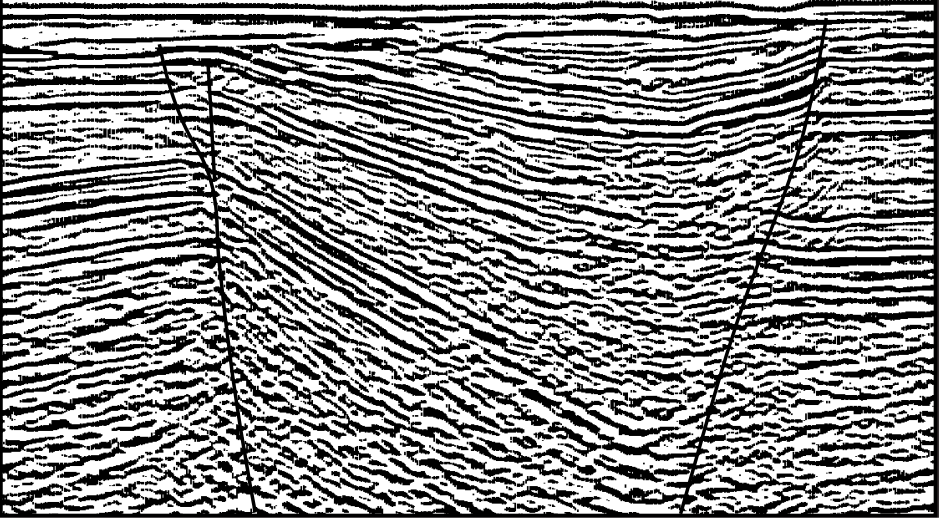

0

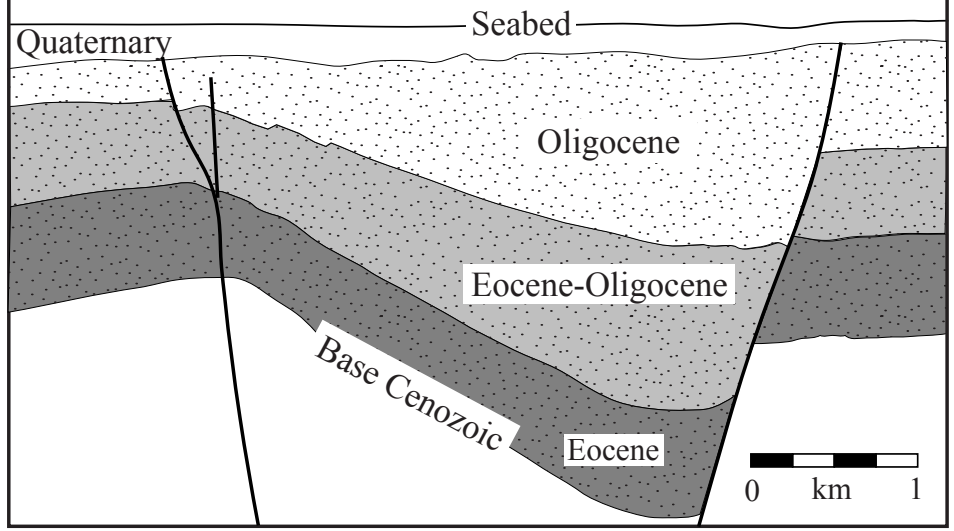

Fig. 10 
Interval transit time (us/m)

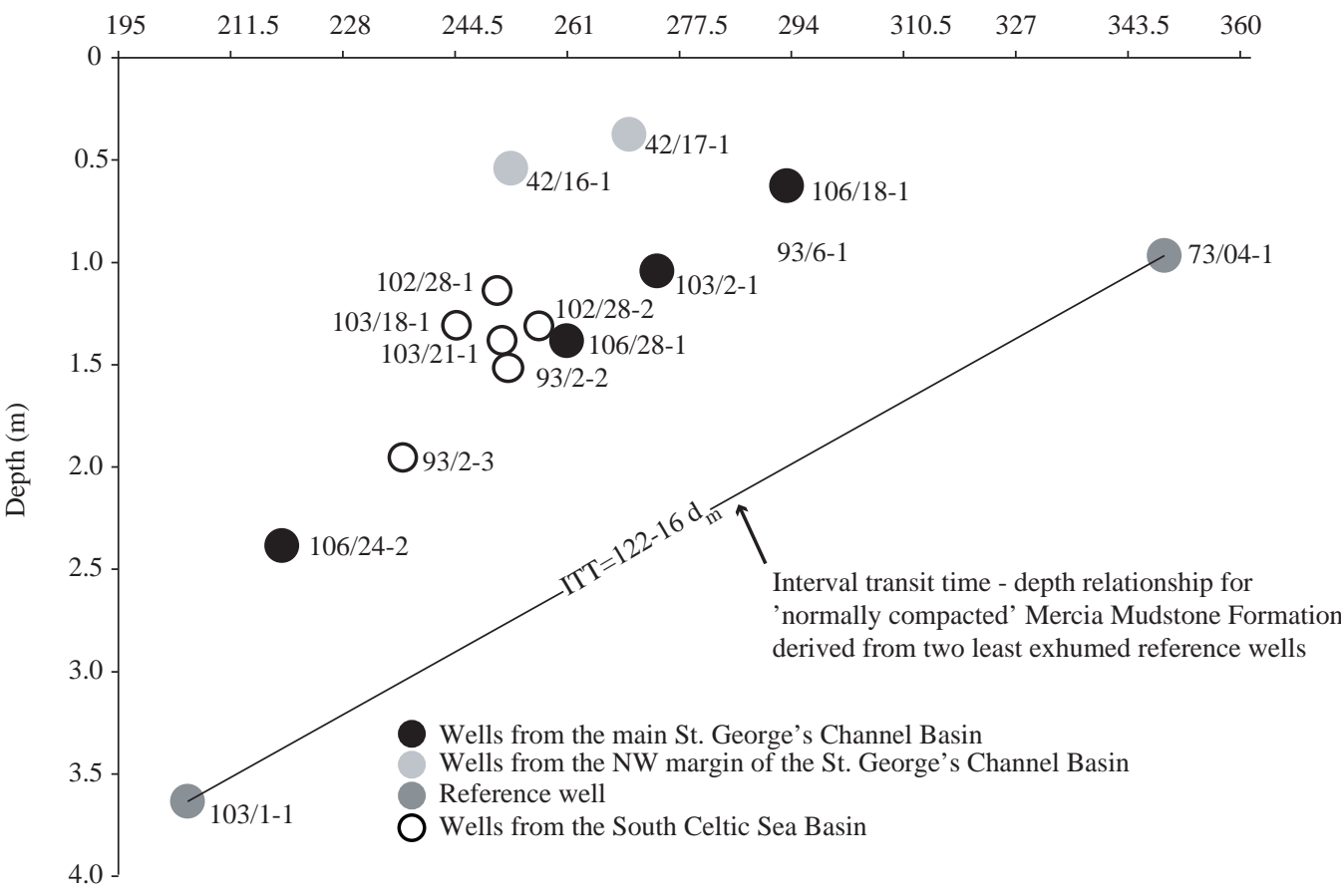


(a) $106 / 24 a-2 b$

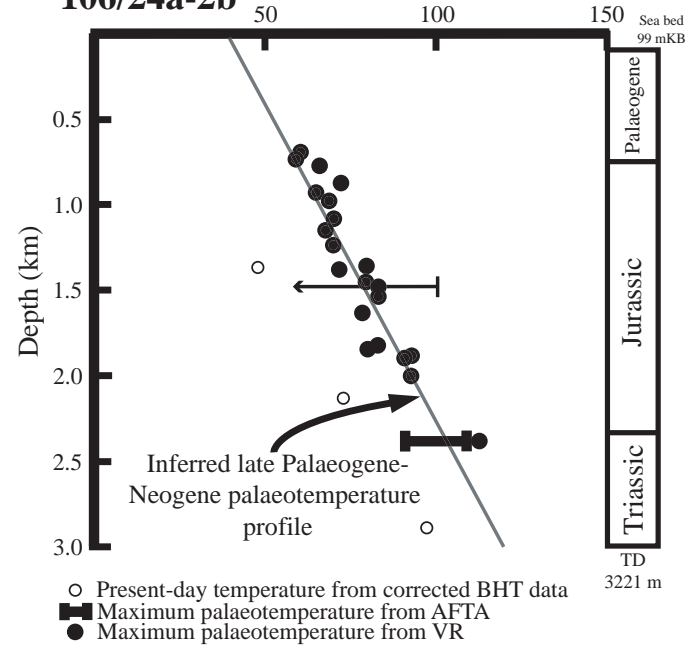

(b)

Late Palaeogene-Neogene surface temperature $=10^{\circ} \mathrm{C}$

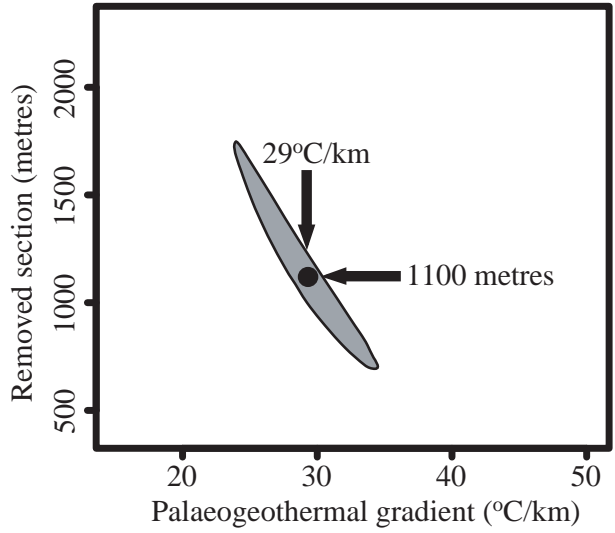

Fig. 13 

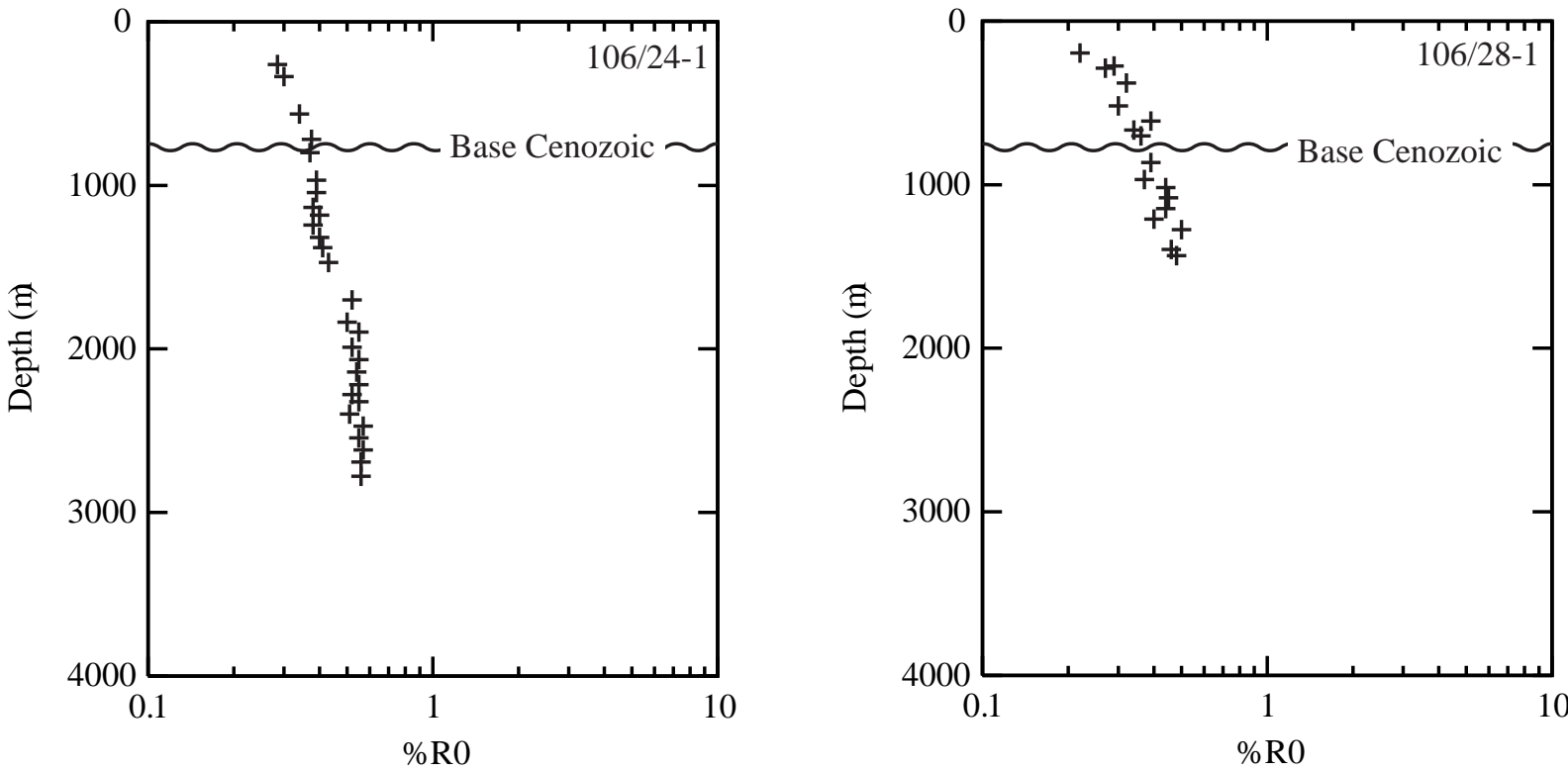

Fig. 14 

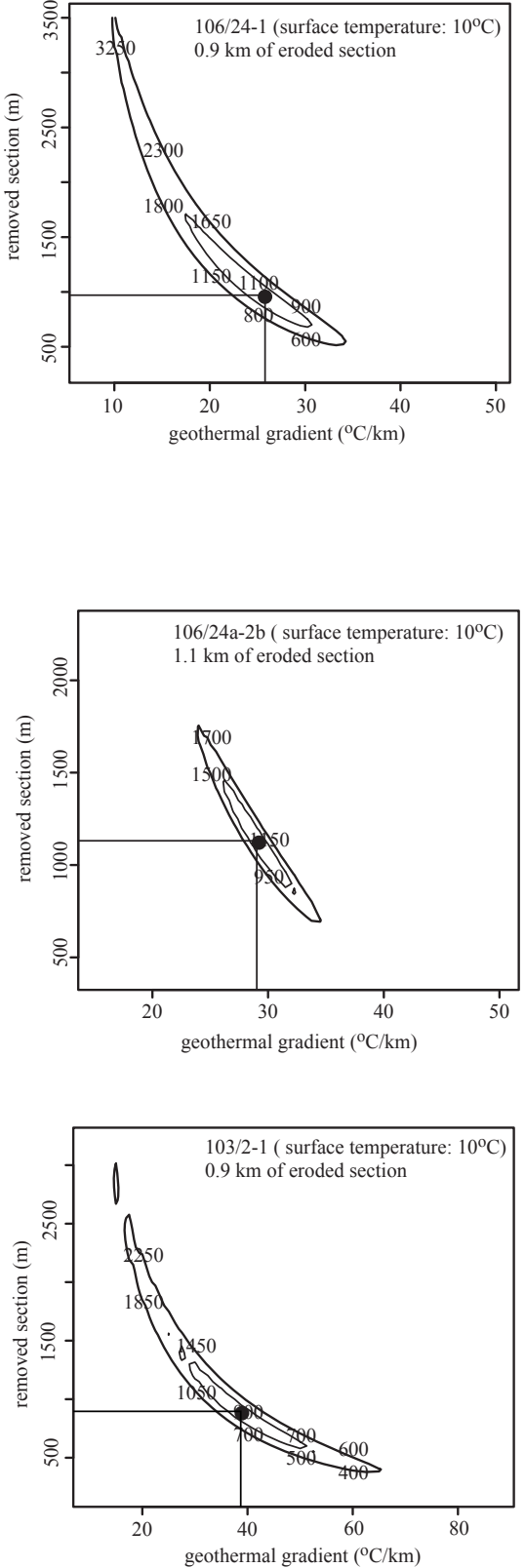
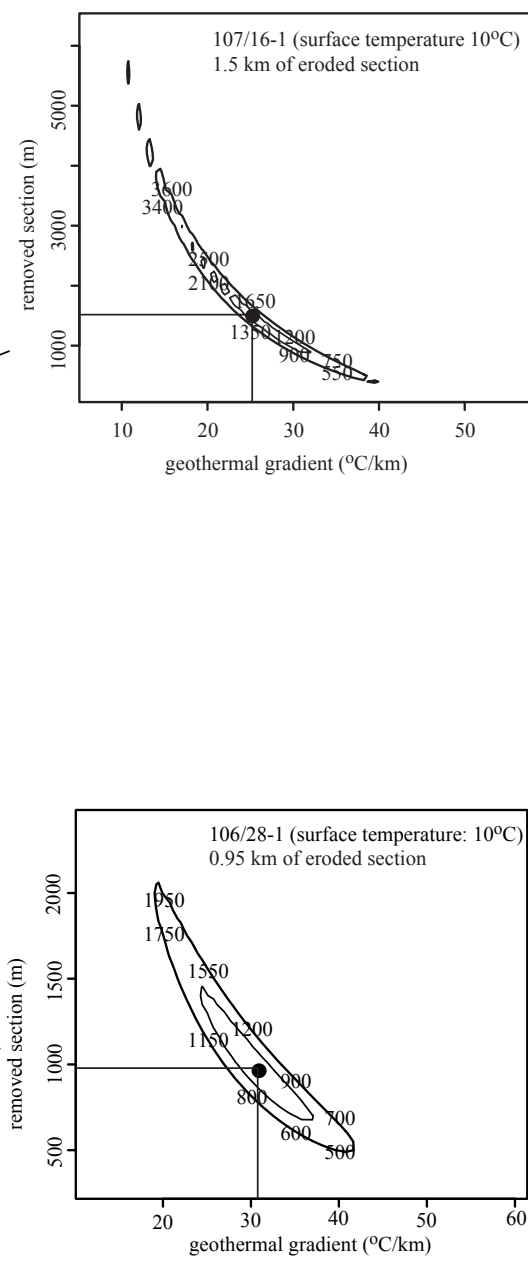

Fig. 15 


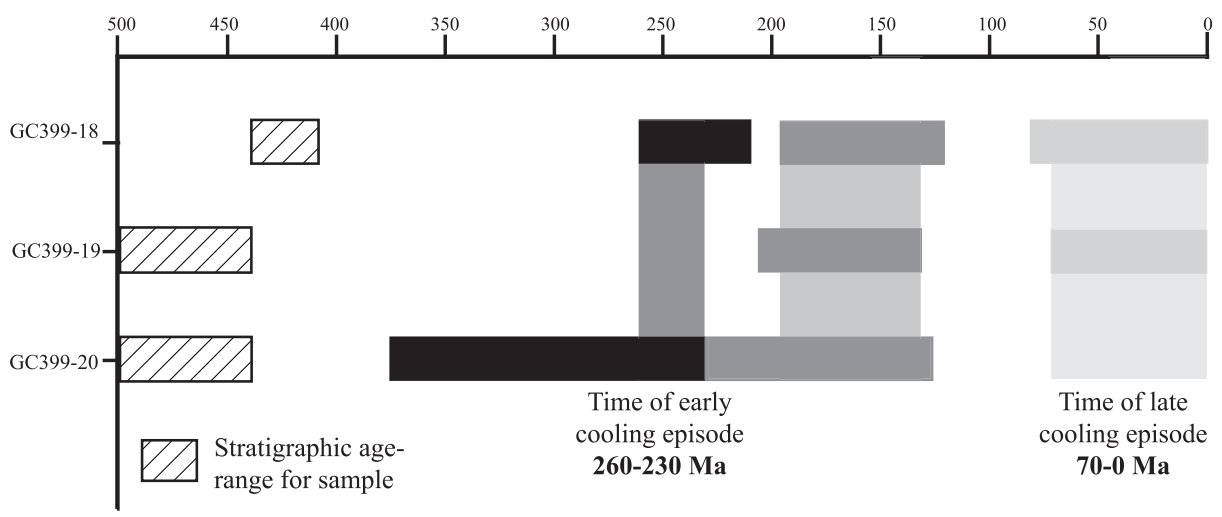

Fig. 16

Simon, could you sort this out. We need patterns not shading and the Figure needs a Better Key. 


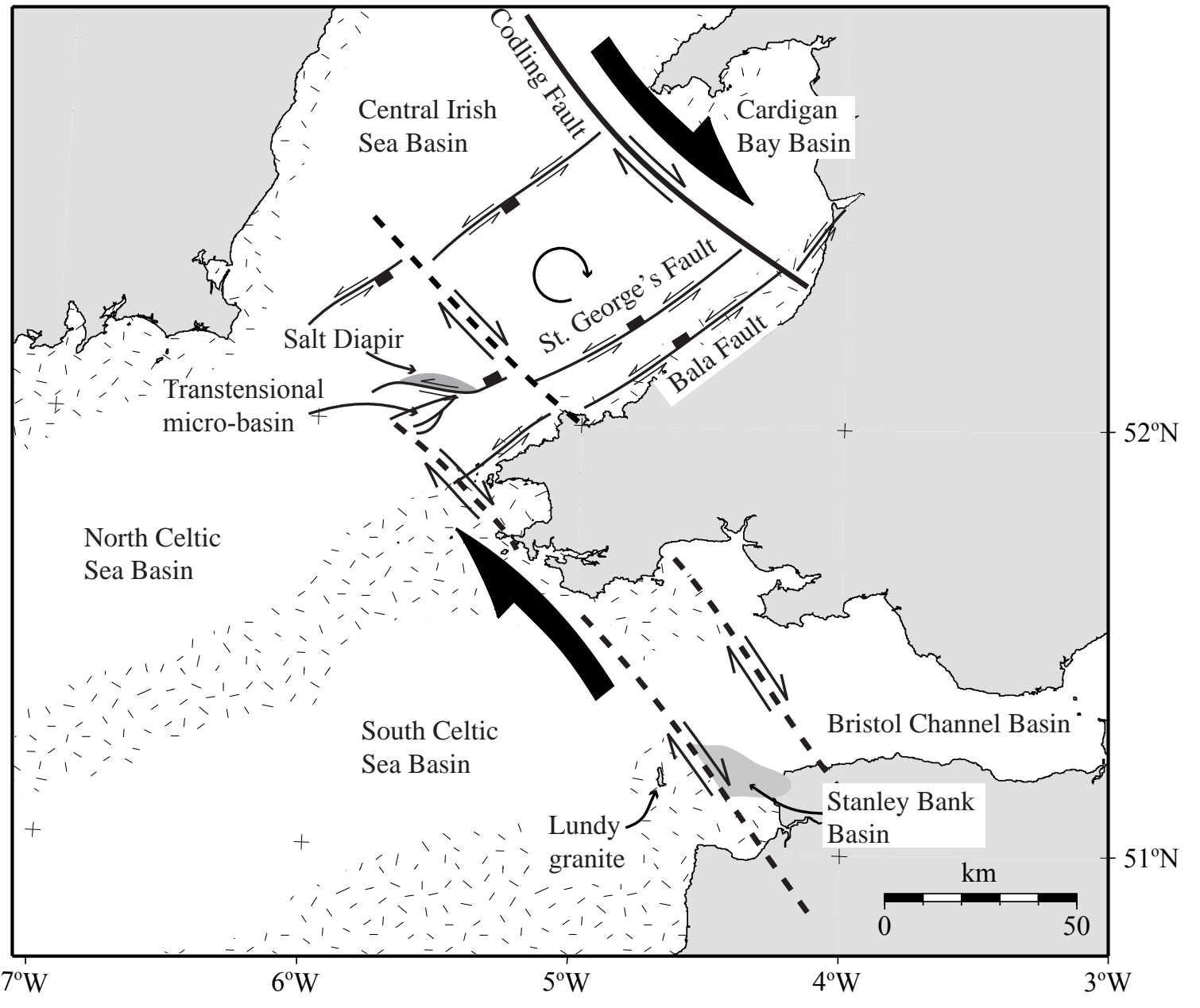

Fig. 17 